\title{
No shame to play: Ludic prosumption on Brazilian fanvideos
}

prosumption

on Brazilian fanvideos

\section{André Luiz Maranhão de Souza-Leão and Bruno Melo Moura Administration Graduate Program, Universidade Federal de Pernambuco, Recife, Brazil, and}
Walber Kaíc da Silva Nunes, Vitor de Moura Rosa Henrique and Italo Rogerio Correia de Santana Administration Undergraduate Program, Universidade Federal de Pernambuco, Recife, Brazil

\section{5}

Received 1 April 2019 Revised 9 August 2019 23 January 2020

Accepted 20 March 2020

\begin{abstract}
Purpose - Fans are proactive consumers of pop culture products, who can be seen as prosumers. Fanvideo production is one of their most widespread practices in the participatory culture scenario. Thus, the aim of the present study is to analyze how ludic prosumption is featured on plays performed in Brazilian fanvideos based on successful pop culture franchises.

Design/methodology/approach - Research based on the interpretive content analysis of fanvideos of plays produced by Brazilian fans based on five emblematic pop culture franchises and published on YouTube.

Findings - Results have shown six play types in the analyzed fanvideos - i.e. child's play, performing powers, cosplay, play in social rites, teaching to play and "zuêra" -, which revealed a way of having fun in different situations through different practices based on ludic consumption experiences in different spheres of social life. Originality/value - CCT-based studies focused on investigating plays as ludic consumption phenomenon, as well as fan culture, remain at early research stage. Thus, the main contribution of the present study lies on associating such concepts based on the concept of prosumption.
\end{abstract}

Keywords Play, Fanvideo, Prosumer, Participatory culture, Ludic consumption

Paper type Research paper

\section{Introduction}

Technological changes have significant impact on different cultural spheres (Lévy, 2007). Pop culture, which has become a significant means of disseminating and legitimizing globalization, is one of these spheres (Kizgin, Jamal, \& Richard, 2018; Peñaloza, 1994), whose strength is mainly ground on media product fans (Hills, 2013). Fans stand out for their significant involvement in, and affectivity toward, products consumed by them and show proactivity and organization in their practices (Jenkins, 2006; Kozinets, 2001).

According to Jenkins (1992), participatory practices are the emblematic feature of these specialized consumers. By means of "poaching" acts, they seek a variety of contents about media products consumed by them, which they appropriate to and re-signify; consequently, they become co-producers of their own consumer experience. It happens because fans feel

(C) André Luiz Maranhão de Souza-Leão, Bruno Melo Moura, Walber Kaíc da Silva Nunes, Vitor de Moura Rosa Henrique and Italo Rogerio Correia de Santana. Published in Revista de Gestão. Published by Emerald Publishing Limited. This article is published under the Creative Commons Attribution (CC BY 4.0) license. Anyone may reproduce, distribute, translate and create derivative works of this article (for both commercial and non-commercial purposes), subject to full attribution to the original publication and authors. The full terms of this license may be seen at: http://creativecommons.org/licences/by/4.0/ legalcode

The National Council for Scientific and Technological Development (CNPq) supported the current research.

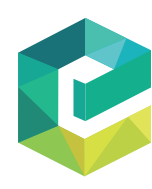

Revista de Gestão Vol. 27 No. 4,2020 pp. 335-352 Emerald Publishing Limited e-ISSN: $2177-8736$ p-ISSN: 1809-2276 DOI 10.1108/REGE-04-2019-0043 
REGE 27,4

\section{6}

responsible for engaging in consumption, as well as for co-creating their consumption experiences (Seregina \& Weijo, 2017; Tumbat \& Belk, 2013).

Based on this perspective, Souza-Leão and Costa (2018) have suggested that fans can be understood as prosumers, since they perform tasks traditionally assumed to be performed by producers, such as promoting and adapting the media products consumed by them. The concept of prosumption is based on production/consumption inseparability (Ritzer, 2014; Tofler, 1980); it has gained new relevance in Web 2.0 scope (Ritzer \& Jurgenson, 2010), since technological appropriation and media convergence have enabled participatory cultures, in which individuals with common interests become collectively productive (Guschwan, 2012; Jenkins, 2006; Sugihartati, 2020). Based on new forms of virtual interactions, mainly on social networks, consumers take responsibility for their production by developing and distributing contents inherent to what they consume (Boulaire, Hervert, \& Graf, 2010; Ritzer, Dean, \& Jurgenson, 2012).

Since the 1970s, fanvideo production is one of the practices that have mostly contributed to fan culture development (Jenkins, 1992). The evolution of video production, editing and distribution techniques has enabled the consolidation of this practice. Nowadays, digital technologies, mainly the ones in Web 2.0, have given fanvideos great relevance amidst fan culture (Freund, 2016; Stein \& Busse, 2009), since it strengthens the relationship between fans and media products (Jenkins, 1992). YouTube, in its turn, has become the main fanvideo distribution channel (Ziller, 2012).

Plays are one of the practices increasingly recorded and widespread through fanvideos. Plays take place as reproduction, reinterpretation and recreation of fan experiences with products they feel connected to, for pure amusement and self-expression purposes (Hetzel, 2002, Mathwick \& Rigdon, 2004). Therefore, plays are a hedonic and autotelic practice that enables ludic interactions among fans, based on elements provided by the products they are based on (Holbrook, Chestnut, Oliva, \& Greenleaf, 1984; Holt, 1995; Mikkonen \& Bajde, 2013). It may happen when individuals get together to play with toys or to perform characters from media franchises.

Based on the argument that fans are prosumers, the present study suggests that fan plays can be called ludic prosumption. The analyzed empirical context lies on Brazilian fans who have produced and published plays on YouTube based on main franchises in the entertainment industry. The aim of the current research was to analyze how ludic prosumption is featured on plays based on successful pop culture franchises performed in Brazilian fanvideos.

The theoretical contribution of the present research lies on the fact that it interconnects different concepts to suggest that fan plays about pop culture refer to ludic prosumption. The economic and social relevance of pop culture justifies the greater attention given to the consumer research field, mainly to its culturalist side. On the other hand, understanding fans as prosumers (Souza-Leão \& Costa, 2018) enables understanding the role played by them in the market productivity logic (Chen, 2011, Collins, 2010). Besides, consumption behaviors of ludic and hedonic nature, as in the case of plays, have been a fertile field of investigation for the Consumer Culture Theory (CCT) since the 1980s (Holbrook \& Hirschman, 1982). Thus, this research aims at endorsing the discussion about how different fan practices can manifest the prosumption disseminated in Web 2.0.

The literature review presents the following key concepts: productive consumption by fans, fanvideos in participatory culture and play as ludic prosumption practice. The methodological procedures indicate how Interpretive Content Analysis (ICA) was used to analyze fanvideos produced by Brazilian fans and posted on YouTube. Results are described through categories and codes, as well as the patterns deriving from the relationships between them, which are illustrated through empirical contexts in the research corpus. The study discusses such results by taking into consideration the research problem. 
The productive consumption of pop culture

Pop culture refers to a range of cultural manifestations available in different formats (e.g. movies, tv series, music, media sports) that adapt to social, technological and economic changes. It has been influenced and spread due to technological evolution and to large media conglomerates, a fact that turns it into one of the main globalization dissemination means (Kizgin, Jamal, \& Richard, 2018; Peñaloza, 1994). Notwithstanding, the relevance given to pop culture mainly results from the performance of its main audience - i.e. specialized consumers known as fans (Jenkins, 2006; Zajc, 2015).

Fans are different from ordinary consumers due to their commitment to products consumed by them; they collaborate with these products by taking intense, coordinated and organized actions, as well as by consolidating and legitimizing values capable of bringing them together around the consumption of media texts (Costa \& Leão, 2017; Hills, 2013). It happens through social interactions among fans (Jenkins, 2006) who show affectivity and feelings toward media products (Chavanat \& Bodet, 2014). Thus, they enable a collective consumption way, which allows them to be acknowledged as a particular consumer subculture (Sandvoss, 2005) featured by its productive capacity - driven by the products consumed by them and by the cultural context they live in (Hills, 2002).

Based on the Consumer Culture Theory, the current study agrees with Souza-Leão and Costa (2018) about the understanding that fans can be characterized as prosumers (see Chen, 2018; Ritzer \& Jurgenson, 2010). This concept was first introduced by Toffler (1980), who advocated that consumers cannot be seen in the passive sense of the term, because they participate in the process of producing goods and services. According to the aforementioned author, the existence of productive consumers dates back to the pre-industrial society; they have gained prominence after technological and cultural transformations that took place over the twentieth century, when consumers started to perform work functions that used to be exclusively attributed to producers.

Despite the brief repercussion of the study by Kotler (1986), the concept of prosumer was not widely adopted until it was resumed and revitalized by Ritzer (2014). The aforementioned author advocated that the production-consumption dichotomy has never existed in fact, that it was more like a concept conceived by industrialization, since all production presupposes consumption and all consumption requires productivity. He suggests that the consumption phenomenon should be understood based on the logic of a continuum between the concept of prosumption as production - relative to typically productive activities - and of prosumption as consumption - inherent to what individuals are used to call consumption. It is possible setting a series of potentially balanced prosumer activities, which tend to one or other extreme of this continuum.

Thus, what it called consumers can only be understood as consumption prosumers, since they are not just limited to consuming, but to perform tasks that were once part of the goods and services provided to them (Cova, Dalli, \& Zwick, 2011). These tasks can be incorporated to goods and services by producers as compulsory and objective activities, as defined by Tofler (1980) and endorsed by Ritzer (2014). But they can also be spontaneously and subjectively performed (Cova \& Cova, 2012; Ritzer \& Jurgenson, 2010) in contexts that take into consideration the productive consumption of fans. The life of these prosumers presents a certain variety and complexity associated with prosumption techniques (Andrews \& Ritzer, 2018).

New information and communication technologies have boosted consumption productivity, which is potentiated by interactions enabled by the web (Almeida, Mazzon, Neto, \& Dholakia, 2012; Gonçalves, Fonseca, Oliveira, \& Tinoco, 2008), mainly due to the democratization enabled by Web 2.0 technologies (Collins, 2010; Laughey, 2010). It happens because fans acquire a collection of materials in the Internet that make it possible for them to prosume (Siuda \& Troszynski, 2017). Ritzer and Jurgenson (2010) have associated the increase in spontaneous prosumption practices with this technology and called these productive

\section{Ludic \\ prosumption \\ on Brazilian fanvideos}

337 
REGE 27,4

\section{8}

consumers Web 2.0 prosumers. The digital environment is a productive place that enables a growing number of practices in which individuals produce contents in activities entailing consumption and production (Dusi, 2016). These individuals present a singular productive ability and strongly influence both the productive process and the popularity of products consumed by them. Thus, new forms of prosuming are developed in the virtual environment and, above all, through the intensive use of social media (Ritzer et al., 2012; Zajc, 2015).

Consequently, Web 2.0 prosumers become specialized consumers and act as coproducers of their own consumer experiences, rather than play a productive role in what they consume (Ritzer, 2014, Stuart-Menteth, Wilson, \& Baker, 2006). It usually happens in a collectively and engaged way (Morreale, 2013; Sugihartati, 2020), when prosumers complement each other's understanding and meaning of products consumed by them through dialogic interactions (Hartmann, 2015; Ritzer, 2014) and take responsibility for redistributing contents to other prosumers (Collins, 2010; Ritzer et al.,2012). After all, digital prosumption provides individuals several ways to produce in a collective way by communicating with each other (Eden, 2017).

If, initially, production right holders had attempted to stop such content redistribution, they nowadays understand that they should incorporate this phenomenon as a market productivity form generated by consumer actions (Chen, 2011; Collins, 2010). Thus, the proactive, spontaneous and dynamic acts performed by prosumers are strong enough to change the entire productive system (Ritzer, 2014; Ritzer \& Jurgenson, 2010).

\section{Fanvideo production as participatory culture}

Recent cultural changes have been mediated by technological devices and influenced by cyberculture (Jenkins, 2006; Lévy, 2007). They allow sharing subjective knowledge to a collective intelligence, which enables a network capable of retaining a vast amount of information deriving from the interaction among Internet users who apply such information in their social practices (Lévy, 2007). Collective intelligence has impact on interactivity and sociability practices and underlies cultural transformations based on the participation of individuals grouped by shared interests, thus enabling the so-called participatory culture (Guschwan, 2012; Jenkins, 2006).

Participatory culture stems from media convergence and technological appropriation (Jenkins, 2006). Media convergence takes place when one moves around between two different media types in order to re-signify consumed contents and transits from socio-cultural isolation to active participation in groups receiving such productions. Individuals participating in such groups engage to objects or topics of shared interest, fact that enables the development of a sense of community and belonging (Jenkins, Ford, \& Green, 2013; Tombleson \& Wolf, 2017). The appropriation of available technology, in its turn, allows using all available means to spread the culture consumed and experienced by them (Jenkins et al., 2013).

Among the available technologies that foster the existence of participatory cultures, social media seem to have revolutionized social interactions among consumers (Micu, Chowdhury, Micu, \& Chaudhuri, 2017; Tapscott \& Williams, 2006; Toffoletti \& Thorpe, 2018). These technologies show how the convergence of relationships between media product producers and consumers works (Jenkins, 2006; Zajc, 2015) and democratize collective intelligence by enabling Internet users to share their thoughts and perceptions about things by publishing and receiving messages about what they consume (Boulaire, Hervet, \& Graf, 2010). In addition, they enable fans to create and popularize contents deriving from media products that can be distributed worldwide without physical and temporal limitations (Jenkins, 2006; Kozinets, 2001; Toffoletti \& Thorpe, 2018).

Since the 1970s, fan culture has evolved and globally spread due to the Web 2.0 phenomenon (Freund, 2016), which made it easier for fans to come together and collaborate with each other to create a collective consciousness (Hewer, Gannon, \& Cordina, 2015; Jenkins, 2006). The complex and multidimensional culture practiced by fans encompass a variety of participation and 
engagement forms (Hills, 2013; Parker, 2019; Sandvoss, 2005). In addition, its productive nature characterizes it as one of the most notorious participatory cultures nowadays, since it contributes to the economic and cultural growth of pop culture and boosts large global media conglomerates (Carpenter, Moore, Doherty, \& Alexander, 2012; Sugihartati, 2020).

Fanvideo production emerges as one of the most emblematic fan practices (Jenkins, 1992). Although their specific motivations may vary, the main reason for video production by fans lies on their intention to recreate official narratives, to adjust them to their preferences and desires, to correct what they see as failure in the media text or to fulfill gaps they have found in the original stories (Freund, 2016; Stein \& Busse, 2009).

Fanvideo production was introduced as an active practice of fans in the 1970s, due to the first home recording and editing technologies such as videocassette recorders and handcams. However, this practice has significantly grown in the last decade due to the easy access to, and use of, digital technologies aimed at recording, editing and distributing contents, mainly in Web 2.0 (Freund, 2016; Stein \& Busse, 2009).

YouTube is the most visited video-sharing portal in the world and one of the leading online content delivery platforms; it became a conduit for fanvideo distribution (Ziller, 2012). The platform is a popular phenomenon that enables publishing videos in an easy way and without the economic burden of disclosure. Therefore, its growth is mostly based on the sense of community it has established among its users, rather than on its innovative technology (Van Djick, 2009; 2013).

Fans express their bond and engagement to media products, as well as to relationships nurtured in the fandom (i.e. community of fans), by producing and sharing videos on the Internet (Rahman, Wing-Sun, \& Cheung, 2012). Thus, they establish relationships with the object of consumption (Bodet, Kenyon, \& Ferrand, 2018) and often become spokespeople or brand lovers to the brands consumed by them (Castellano, Pinho, \& Noronha, 2018). In addition, they show strong desire to create and engage to the fandom (Castellano, Pinho, \& Noronha, 2018; Cristofari \& Guitton, 2017; Fuschillo, 2020; Waysdorf \& Reijnders, 2019). This behavior is aligned with that of consumption tribes, which is based on rituals, traditions and moral responsibilities (Cova \& Cova, 2012) and depicts fans as active consumers who produce and consume cultural products (Parker, 2019; Sugihartati, 2020).

Fan culture often encourages the emergence of new professionals and shapes the existing products (Cristofari \& Guitton, 2017; Fuschillo, 2020), a fact that generates the sense of belonging, identity and status among fans (Chung, Farrelly, Beverland, \& Karpen, 2018; Seregina \& Schouten, 2017). According to Jenkins, Ford and Green (2013) some fans feel responsible for the culture they belong to; thus, they take the task of spreading it to help consolidating it. Kozinets (1999) has pointed out that this is a common practice performed by online community leaders in virtual fandoms; they produce contents faithful to the original products in order to perpetuate the culture consumed by them. Thus, since the immaterial work of fans can add strong value to brands, they undergo repeated attempts to be controlled by them through the creation of brandoms - i.e. brand-controlled fan communities (Bodet et al., 2018; Fresco, 2017; Guschwan, 2012). However, fan production results from their freedom of creating things based on the genuine love they feel for the products consumed by them, rather than for profit (Parker, 2019; Sugihartati, 2020).

\section{Digital play as ludic prosumption}

An important fan activity performed in the diffuse Web 2.0 scenario lies on creating their own contents (Freund, 2016; Guschwan, 2012; Jenkins, 2006). One of these contents refers to recording and publishing plays, which are a voluntary and captivating consumption act. Plays are unpretentious of material interests and able to reveal cultural aspects of social groups experiencing hedonic situations through them (Holbrook, Chestnut, Oliva, \& Greenleaf, 1984; 
REGE 27,4

\section{0}

Seregina \& Weijo, 2017); moreover, they are a necessary activity found in a variety of social domains (Seregina \& Weijo, 2017) where experience is what matters the most (Pantzar, 2000).

Plays are a practice experienced by fans based on the reproduction, reinterpretation or recreation of consumer experience aspects in order to enable amusement or self-expression (Hetzel, 2002; Mathwick \& Rigdon, 2004). They allow relationships between consumers who identify themselves with the same products, since they are an autotelic practice that is an end in itself (Kozinets et al., 2004). Thus, plays do not have further purposes and their process is more important than their outcome (Holt, 1995; Pantzar, 2000). They can be understood as a practice capable of seducing consumers (Kozinets, Sherry, Storm, Duhachek, Nuttavuthisit, \& DeBerry-Spence, 2004).

Since contemporary consumers no longer have dilemmas about turning explicit consumption into a hedonic practice, they advocated for and perform practices associated with brands and products in a spontaneous and independent way (Hetzel, 2002). Therefore, it is a hedonic consumption experience that emerges as fun, escapism, pursuit of emotion and competition and as a way to externalize emotional responses intrinsic to consumer's identification with consumption objects (Holbrook, Chestnut, Oliva, \& Greenleaf, 1984; Holt, 1995; Mikkonen \& Bajde, 2013).

Hence, the object of consumption is essential to the practice of play, since it provides the elements for ludic interactions to take place (Holt, 1995) through the collaboration and socialization among individuals with common interests (Holt, 1995; Jenkins, 2006). This ludic dimension can manifest itself through the most diverse product types; besides, it is seen in consume situations where individuals interact with each other in an active and independent way (Holbrook, 1999). Since ludic experiences are typically considered as marketer's responsibility, the active and spontaneous participation of consumers plays an important role in influencing the symbolic, verbal or emotional perception in consumers' experience. Ludic consumption turns consumers into co-creators of their experiences (Seregina \& Weijo, 2017; Tumbat \& Belk, 2013).

Plays are a ludic social activity always associated with other play activities inserted in different contexts (Buchanan-Oliver \& Seo, 2012). They are essential to communal consumption, since they are a type of ludic consumption embedded in a given culture increasingly associated with technology in the contemporary world - it encourages consumers to interact with each other (Seregina \& Weijo, 2017; Tumbat \& Belk, 2013).

Transformations resulting from the widespread adoption of digital technologies have impact on the way people learn to play (Squire, 2011). Thus, plays have recently penetrated the digital world due to the development of the entertainment industry, which is strongly driven by technological advancements (Kline, Dyer-Witheford, \& De Peuter, 2003; Molesworth \& Denegri-Knott, 2007). Media images play a key role in forming the relationship between consumers and their fantasies, besides having direct impact on the demand for goods and services (Kozinets et al., 2004). Thus, interactive media allows consumers to use available technologies as a way to maximize their fantasies and to experience possibilities that were previously restricted to their imagination (Molesworth \& Denegri-Knott, 2007), since media and consumer cultures are empirically inseparable (Kozinets, Sherry, Storm, Duhachek, Nuttavuthisit, \& DeBerry-Spence, 2004). The representativeness of plays in virtual spaces has gone beyond the perception that it is a superficial, frivolous and little relevant experience to other spheres of individuals' lives (Molesworth \& Denegri-Knott, 2007).

\section{Methodological procedures}

The current study has investigated fanvideos produced by Brazilian fans and published on YouTube. They can be considered as visual documents, since the herein collected videos refer to secondary data (Flick, 2014; Loizos, 2013); besides, they are a multifocal kind of data (e.g. film, photograph, video, audio), whose format involves the combination of more than one 
sense (Flick, 2014; Loizos, 2013). This factor allows researchers to analyze the social practices they represent (Flick, 2014).

The literature in the field was used as basis for study conceptualization and as lens for result interpretation, rather than as provider of a priori conceptual categories for research implementation purposes (Leão, Mello, \& Vieira, 2009). This approach is aligned to the interpretive research paradigm (Lincoln, Lynham, \& Guba, 2018). Moreover, the research problem was developed by taking into consideration the original alignment between different concepts, rather than a verificationist approach based on theoretical constructs.

ICA was herein adopted as analytical method; it is an adequate approach to help better understanding the plurality of meanings found in a given content (Baxter, 1991). Despite being a type of content analysis, this variant - as its name indicates - is in line with the interpretive approach to research (Wester \& Jankowski, 2002). Thus, ICA goes beyond the purely lexical and semantic levels characterizing the most traditional approaches to content analysis (Drisko \& Maschi, 2015); it holistically addresses the whole context where contents are inserted in (Ahuvia, 2001).

ICA should preferably be performed by more than one researcher, in a collaborative work (Ahuvia, 2001), which requires the exercise of self-reflection and reflexivity in order to prevent personal biases in data interpretation (Drisko \& Maschi, 2015). This process avoids inadequacies in research corpus' categorization (Montgomery \& Duck, 1991).

ICA execution begins with a data collection process in which researchers define their data source and create criteria or filters in order to qualify them. Data selection is based on their relevance for the phenomenon to be investigated. The analysis itself is guided by a data codification process based on hierarchical and interrelationship schemes, and it generates propositions and definitions of codes and relationships representing the research problem (Drisko \& Maschi, 2015).

Preliminary data evaluation has indicated that the production of Brazilian fanvideos based on plays focused on five emblematic pop culture franchises, which were defined as research scope, namely: Dragon Ball, Harry Potter, Naruto, Saint Seiya and Star Wars. Besides representing the largest number of plays in fanvideos produced by Brazilian fans, they figure among the most representative pop culture franchises. Star Wars is the most profitable movie franchise, because several products have been associated with it (e.g. animations, comics, books, toys, fair) since it was released in the 1970s (Jenkins, 2006). Harry Potter is a popular culture phenomenon both in books and movies, which were released from 1997 to 2011 (Souza-Leão \& Costa, 2018). Star Wars, Harry Potter and Dragon Ball are among the highest-grossing media franchises of all times (Max, 2020). Naruto is considered the most popular anime of the 2000s; it mobilized fans around the world to mimic franchise characters (Milan, 2019). Saint Seyia was the first anime (i.e. Japanese animation) to become an emblematic audience phenomenon in Brazil in the 1990s, whereas Dragon Ball, which was released a few years later, is the most loved animation among Brazilian fans (Canabaro, 2018).

Three video selection criteria were herein defined: they should feature some type of fan production in compliance with the research problem; they should be produced by Brazilian fans to meet the scope of the investigation; and they should not have aimed at having pecuniary gains to feature the amateur practice of fans.

Data collection began with a keyword-based search conducted on YouTube, which is the world's major video sharing platform (Giglietto, Rossi, \& Bennato, 2012; Tourinho, Medeiros, Salvador, Castro, \& Santos, 2012). The first step was intuitively run, since it used the platform's searching tool to find Brazilian fanvideos based on famous pop culture franchises. Videos characterized as records of play were selected among the identified ones. As the platform indicates videos associated with the ones being played, all videos indicated due to association with a given collected video were checked, until it got to the point where all associated videos were collected. The automatic recommendation of videos on YouTube

\section{prosumption \\ on Brazilian fanvideos}

Ludic

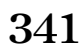


REGE 27,4

derives from algorithms aimed at cultivating a mainstream cycle on the media (Tourinho, Medeiros, Salvador, Castro, \& Santos, 2012). Thus, video collection based on such recommendations is one of the most efficient ways to reach associated videos. Based on this exhaustive process, it was possible assuring the representativeness of the research corpus (Aarts \& Bauer, 2013). The total number of 640 videos published from March 23rd, 2006 to May 29th, 2019 were analyzed.

The analysis of the selected videos comprised three stages: first, videos were classified based on technical and narrative features and on the way the franchises are employed; next, these categories were codified according the way they were empirically manifested; finally, associations between codes were analyzed in a syntactic way in relation to the categories, which allowed identifying patterns in the production of the analyzed videos.

Data were collected by three researchers, whereas two others defined the videos composing the research corpus. One of these two researchers was responsible for defining the analytical categories (first analysis stage), whereas the very same three data collectors have coded the corpus in an inter-coding reliable process (Miles, Huberman, \& Saldana, 2014). The pair responsible for validating the research corpus provided support to and reviewed this process, as well as validated the codification and the final definition of these codes (second analysis stage). Finally, the same pair has analyzed the associations between codes and set the standards for the research corpus (third analysis stage).

Finally, it is worth emphasizing that the criteria adopted for research corpus construction and for data analysis processes, as well as the subsequent rich and detailed description, have met qualitative-research quality criteria (Paiva, Leão, \& Mello, 2011).

\section{Categories and codes describing fanvideos}

Seven categories were identified based on the analytical procedure adopted in the current study (first analytical stage); each category comprised a number of codes (second analytical stage). These categories and codes characterized the fanvideos themselves, which were classified based on them. Two categories took into consideration the technical features of the analyzed videos, two were based on their narrative aspects and three were based on how franchises are used.

Production format was the first technical category. All videos were produced in live action; shooting was performed in certain places or scenarios, with the participation of people; and visual effects were used in some cases. These videos had two production forms (second technical category): original videos, which are audiovisual productions created and produced by fans; and compositions, which refer to videos originally created by fans, added with official franchise materials.

The first narrative category classified the analyzed material based on its genre. It comprised storytelling, which refers to the development of stories or to the presentation of situations based on, or about, the franchises; thematizations, which refers to the use of franchise aspects as subject of everyday situations; tutorials, which teach how to emulate practices performed in the franchises; and parodies, which refer to the imitation of, or jocular references to, the original work (or based on it).

The second narrative category refers to the adopted narrative technique. It takes place in six different ways, three of them are associated with situations where fans act scenically, namely: simple representations where fanvideo actors use common clothes; representations with costumes where fanvideo actors use costumes allusive to the franchises; and representations by cosplay where fanvideo actors use authentic franchise costumes. The other three ways comprise puppetry, when stories based on the franchises are staged with toys or objects; accessories to real life, which refers to the use of official franchise materials; and amateur videos about, or inspired, by the franchises. 
As for the way franchises are used, the first category refers to franchise references used to guide narrative development. There are videos produced to reflect the franchise itself (internal) and productions mixing the franchise repercussion with other subject matters (mixed).

The next category points toward the franchise approach, which means the way fans use the official narrative in their production. When the official narrative is used as central reference to deal with other issues, the process is categorized as franchise appropriation. Franchise-based videos use franchises as central references to produce materials external to their fictional universe. Fans also act by making performances of franchises narrative universes. Satires based on franchises are presented in a caricatural way. Finally, fans make use of franchise elements when some of their aspects are used in contexts external to their fictional universe.

Finally, franchises are adopted in relation to a certain topic, which indicates the aim of the content addressed in the videos. It happens in four different ways, two of them are associated with franchise dimensions in video productions. They can be plotted in association with their own narrative and elements (intra-universe) or in compliance with real life elements (parauniverse). There are also stories adhering to the fictional universe of franchises, although without contiguity with some established narrative (invented sagas and mockery), when the franchise is scoffed or serves as reference for the derision of other subject matters.

\section{Plays in fanvideos}

The analysis applied to the association between codes, and to how they are combined to the categories, allowed identifying six play patterns (third analysis stage); each of them is presented by a definition based on the association between its constitutive codes (in bold) and its empirical context.

\section{Child's play}

Part of the videos are records of children playing with franchise toys. They are original productions of created (invented saga) storytelling, based on sagas and adherent to their fictional universe (internal reference), which use toys as puppetries. A video based on the Star Wars franchise has created a story to narrate adventures involving the character Poe Dameron and his spaceship (X-Wing), which were represented by official toys of the saga. In another video, Naruto action figures were used to emulate fights between characters of the fictional universe. In the same line, Dragon Ball fans gathered franchise dolls to narrate imagined battles between them. As for the Saint Seyia franchise, battles of the original story were staged using toys to represent characters of the fictional universe.

Harry Potter was the only franchise in the study that was not identified in this category, likely because the franchise does not have children as target audience to its canonical materials (i.e. movies and books). The other ones, in their turn, were animes (Saint Seiya, Dragon Ball and Naruto) or had cartoons as product extensions (Star Wars), as well as produced toys of their main characters and equipment.

Child's play evidences children's imaginative ability to create stories as background for their play, which are consistent with the narratives of the sagas (Buchanan-Oliver \& Seo, 2012; Molesworth \& Denegri-Knott, 2007). It is the self-production of consumers' experience that features such videos as fan productions (Ritzer, 2014, Stuart-Menteth, Wilson, \& Baker, 2006).

\section{Performing powers}

This pattern is featured by the record of fans playing performing powers found in the franchises; it happens both by mystical invocation and by training, almost always in public places. It is seen in practices and duels typical of these fictional universes, based on gestures 
REGE 27,4

\section{4}

or equipment (use of franchise elements), whether they are official merchandises or objects adapted for this purpose. There are lightsaber duels, as well as training to improve its use (Star Wars); duels of wands, as well as the conjuring of spells using them (Harry Potter); imitation of poses and rituals performed by powerful characters (Dragon Ball, Naruto and Saint Seiya); and duels with blows (Naruto and Dragon Ball).

According to a video based on Saint Seyia, a fan, in a solo performance, mimics some lines and poses of the main characters, which are used to evoke their most powerful blows (e.g. Pegasus meteor fist). In another video, two fans of Dragon Ball stage a battle that allows reaching the highest level of power in the franchise (i.e. Super sayajin). Another video shows a fan mimicking Naruto's iconic scream (i.e. Rasengan) while using his fist to attack another fan who has a special power. In Harry Potter-based videos, fans use wands - official merchandise or pieces of wood - to conjure incantations to open doors or brighten the environment (i.e. Alohomora, Lumus), as well as spells to torture or kill their enemies (i.e. Crucio, Avada kedavra). In the case of Star Wars, fans use effects to simulate the training or the awakening of the Jedi powers; they move objects or shoot lightning through their hands - a dark technique from the Sith, major franchise villains. They also duel with lightsabers - be them official merchandise or bits of broom -, sometimes they reproduce iconic fights in the franchise (i.e. Anakin Skywalker vs Obi-Wan Kenobi in Episode III; Luke Skywalker vs Darth Vader in Episode V).

They are original videos, which present reliable (internal reference) situations based on the sagas (storytelling) in a real-life context (para-universe of the saga). Most of the time, fans wear ordinary robes (simple representation), mainly because they are recording ordinary life situations. However, in case of duels, Harry Potter and Star Wars fans also wear costumes and some "Jedi" make cosplay. In the case of the two franchises, it usually happens in association with the use of official wands and lightsabers, which may explain the elaborated clothing.

Some videos used edition effects, as well as artifacts emulating the original ones, in order to give more veracity to the gestures and equipment. Thus, light effects coming out from objects in fans' hands replaced the official Star Wars lightsabers. In the case of Harry Potter, the same resource was used to emulate the rays coming out of the wands. Besides, fans also used fireworks in the place of wands. Naruto fans used effects to make copies of themselves and elements of nature, such as thunders and hurricanes, to emulate the powers of the most famous ninja jutsus. As for Dragon Ball, the effects aimed at reproducing special aura attacks and stronger battle modes known as super sayajin. Finally, Saint Seiya fans inserted effects of physical impacts caused by the most powerful blows of the franchise protagonists, such as reverting waterfalls, freezing environments and blazing flames.

Performing powers indicates fans' desire to experience the stories they admire for pure hedonic experience (Hetzel, 2002; Holt, 1995; Pantzar, 2000), which says a great deal about their involvement with the franchises (Holbrook, Chestnut, Oliva, \& Greenleaf, 1984; Holt, 1995; Mikkonen \& Bajde, 2013). Finally, it is worth highlighting the use of artifacts to emulate franchise equipment and the mastering of video editing resources by fans who show creativity and expertise (Ritzer \& Jurgenson, 2010; Stein \& Busse, 2009).

\section{Cosplaying}

Only the duels of the Saint Seiya franchise were not observed among all possibilities of performing powers. Combats between fans were seen in representations by cosplay in anime events, in performances of the narrative universe (intra-universe of the saga) involving characters and situations (storytelling) of the franchise (internal reference), with the use of official materials (compositions).

There were videos showing parade and acting performances. As an example of the first case, a video recorded a fan taking the stage to present his cosplay. Videos of the portrayed 
character were displayed on a large screen behind the fan, which allowed seeing the characterization reliability level. In an acting case, fans made playback of original Brazilian dubbed voices in duels where powers were invoked. In either case, fans performed franchise characters supported by original scene plays. The finding of this variation of play only in the case of Saint Seiya fans can be associated with the mystique powers attributed to the armors that give strength to the characters of this fictional universe. In addition, it is mainly a play performed by adult individuals who can afford the high cost of this production type.

Cosplaying concerns reliable characterizations and performances capable of enhancing and spreading media products. Denison (2011) reveals how fans aim to make their practices adhere to the pop cosmopolitanism (Jenkins, 2006; Zajc, 2015). More specifically, such practice is one of the most celebrated ways to strengthen ties in the fandom (Rahman et al., 2012), as well as to crystallize rituals, traditions and moral responsibilities in the community (Cova \& Cova, 2012).

\section{Playing in social rites}

In another adult play, fans appropriate the saga to characterize social rites (para-universe of the saga). This way of playing embeds, rather than just inserts, the franchise in real life (mixed reference). It happens in two sorts of situations. In one of them, videos about wedding ceremonies and sweet fifteen parties narrate them as part of the fictional universe of Star Wars (storytelling). They are produced with materials of the saga both in their edition (composition) and in presented situations (accessories to real life); sometimes fanvideo actors use costumes. In a video recording a sweet fifteen party, guests featured characters from the fictional universe and used lightsabers in a choreography rehearsed in sync to the theme song of the franchise movies.

In the second situation, original videos recorded social rites using the franchise as background (thematization). A typical example of this situation lies on playing Star Wars and Harry Potter soundtracks while brides walk down the aisle in the church (accessories to real life). In a Harry Potter fanvideo, the groom plays the franchise theme song in the trumpet while he enters the church in his wedding ceremony. In several other videos, brides and grooms walk toward the altar to the sound of Imperial's March, Darth Vader's theme song. Star Wars fans also represent characters and make lightsaber duels in marriage proposals, wedding ceremonies and sweet fifteen parties; they wear clothes inherent to these rites (simple representation), costumes and make cosplay. One of the videos features a fan duel on the stage of a pop culture event. A girl plays Ray and her boyfriend plays Kylo Ren - the main character and the antagonist of the new film trilogy, respectively. The duel ends up in his defeat, when he takes the opportunity to kneel and propose to her.

The introduction of narrative elements of the sagas into traditional social rites appears to corroborate the relevance and legitimacy that pop culture has acquired in the globalized world (Freund, 2016; Kizgin, Jamal, \& Richard, 2018). In addition, it confirms the meaning that this kind of product has for its fans, since it takes part at fundamental moments of their lives (Holbrook, Chestnut, Oliva, \& Greenleaf, 1984; Holt, 1995; Mikkonen \& Bajde, 2013). On the other hand, the introduction of narrative elements of the sagas into traditional social rites indicates to what extent the ludic dimension of life (Buchanan-Oliver \& Seo, 2012) is increasingly attached to formal contexts and behaviors.

\section{Teaching to play}

Specifically, in the case of Naruto, fans produce original amateur videos to explain (tutorial) to other fans how to do (para-universe of the saga) perform jutsus (use of saga elements) in a proper way (internal reference). They are manual gestures referring to the Chinese zodiac 
REGE 27,4

\section{6}

animals. The combined gestures allow anime characters to perform extraordinary fight and attack techniques. A particular fan has published several videos detailing the hand gestures used to perform the signals to summon different special attacks (e.g. fireball, chidori, transformation) from the fictional universe.

Videos of this type of play focus on explaining, in a didactic way, how to make the right gestures to reproduce the signals made by the characters of the saga and their association with the special techniques they intend to reproduce. Performing jutsus is a very popular play for Naruto fans because it requires memorization skills and speed to accomplish them in a precise and fast way.

Teaching to play shows a sense of responsibility of Naruto fans to stay true to the franchise canonical content and to their desire to spread it (Jenkins, Ford, \& Green, 2013). By engaging in this task, video producers become community leaders (Kozinets, 1999). Nevertheless, once this practice resonates among fans, it can be understood as a collective intelligence exercise (Guschwan, 2012; Jenkins, 2006).

\section{The "zuêra" never ends!}

A singular pattern of play is based on parodic production. Parodies are original videos where fans play by representing the franchises (internal reference) in a satirical (mockery) way, which is called "zuêra" in the Brazilian social media. Simple representations prevail in these videos, but they also use costumes and even objects for puppetry purposes.

Harry Potter fans mimic scenes from the movies in a comical way, they play with ordinary brooms as if they were flying and simulate spells in ordinary or jocose situations. In a video called "Brazilian Harry Potter", a fan used a stick to simulate a wand in order to conjure a spell by changing its original name from "Wingardium leviosa" to "Wingardium lave-louça", which in Portuguese means to clean the dishes. Star Wars fans mimics Chewbacca's howling, Darth Vader's breathing and even the sound of the lightsaber, as well as clumsily emulate duels with such weapon and stage the mythical scene in which Darth Vader tells Luke Skywalker he is his father. In one of the several videos depicting the representation of this emblematic scene in a satirical way, a fan who plays Luke Skywalker states that Darth Vader's lightsaber cannot hurt him because it is made of plastic-he evokes the real context of the recording. Naruto fans gather in public places to replicate the way the saga's ninjas move in events called "Naruto Run", which are scheduled through social networks. Following a worldwide Web movement, franchise fans recorded videos showing a large number of them by running with their arms extended behind their backs, in the way characters do. These videos were recorded in several cities in all Brazilian regions. Dragon Ball and Saint Seiya fans practice the so-called "cospoor", which a jocular and satirical version of the cosplay. They try to characterize those franchise characters with unusual materials of easy access. It can happen due to lack of financial conditions to do elaborated cosplays or to highlight features of the satirized characters. In a Saint Seyia-based video, fans wearing homemade garments made of boxes and styrofoam emulate the knights' armor and reproduce the franchise opening while making fussy gestures and poses. In another video, a Dragon Ball fan uses plastic bags to emulate colored hair in order to represent the highest power level in the saga (i.e. Super Sayajin).

In a very peculiar way, "zuêra" reinterprets and recreates narrative aspects of the sagas (Hetzel, 2002; Mathwick \& Rigdon, 2004) in a type of radically autotelic play (Holt, 1995; Pantzar, 2000). The practice shows how the elements of a media product can be appropriated by fans (Holt, 1995) in a completely autonomous way in comparison to the one planned by their creators (Ritzer, 2014; Ritzer \& Jurgenson, 2010). This factor points toward a seemingly reversed market productivity (Chen, 2011; Collins, 2010) that reveals the affection of fans (Chavanat \& Bodet, 2014) for these franchises. 


\section{Conclusion}

The patterns of play identified in the analyzed Brazilian fanvideos have indicated the use of pop culture narratives as a way to have fun through a variety of practices performed in different contexts. They also revealed ludic consumption activities carried out in different spheres of social life. Thus, Brazilian fanvideos have shown that plays based on successful pop culture franchises are ludic prosumption experiences. The way ludic prosumption was featured in fanvideos allowed reasoning about aspects that go beyond the ones presented in each concept analyzed in separate (i.e. play, ludic consumption, prosumption). Thus, the current research provided some insights and contributions to this research field.

First, the study brought to light how plays express fan creativity associated with different emotions and situations (e.g. humor, passion, social life, childhood). Creative content in fan culture is mainly produced to be shared in social media (Chen, 2018), as a means of re-signifying, imagining and materializing new possibilities for media products (Seregina \& Weijo, 2017).

On the other hand, the entertainment industry should encourage such creative process, since it is a fan-productivity means (Chen, 2018). This process become an emotional rhetoric in which consumers commit to the products they are fans of and engage in solidarity and loyalty along with their peers (Edwards, 2019; Seregina \& Schouten, 2017).

Besides, this bond among fans is channeled into the fandom engagement (Guschwan, 2012; Hills \& Greco, 2015). Fans often develop a sense of collectivity and responsibility, mainly in the space of the fandom (Parmentier \& Fischer, 2015). The current results show how plays are used by fandoms to keep fans attached. On the other hand, plays are also used as important modus operandi in conveying and preserving their ethos.

Finally, the use of social networks, such as YouTube, to promote fanvideos shows the familiarity fans have with Web 2.0, based on information and communication technologies to evidence the consequence of technological appropriation - typical of the convergence culture (Guschwan, 2012; Jenkins, 2006). The fanvideo production highlights the relevance of technologies to fan culture perpetuation (Freund, 2016) by allowing a huge volume of UserGenerated Content (Liu-Thompkins \& Rogerson, 2012; Presi, Saridakis, \& Hartmans, 2014).

Although the research has focused on the production of Brazilian fanvideos, it is not possible, based on its results, to identify a Brazilian way of playing based on pop culture narratives. It is possible wondering that such phenomenon has a global character (Kizgin et al., 2018; Peñaloza, 1994) and does not appear to be affected, at least in a specific way, by local cultures. The production of fanvideos of play may be associated with global collective intelligence (Guschwan, 2012; Jenkins, 2006; Lévy, 2007) and works in participatory cyberculture (Jenkins, 2006; Lévy, 2007). This aspect may indicate a potential theoretical generalization of findings.

"Play" as ludic consumption and fan culture are in early research stage in CCT. They must be associated in light of the sense of presumption, which is the main contribution of the present study. This line of research can be expanded by analyses applied to fanvideos produced in other locations and cultures, as well as by observing offline practices recorded on them. Accumulation of knowledge about the investigated phenomenon would make it possible to theorize about the topic.

\section{References}

Aarts, B., \& Bauer, M. (2013). Corpus construction: A principle for qualitative data collection. In M. Bauer \& G. Gaskell (Eds.), Qualitative researching with text, image and sound. Thousand Oaks: Sage Publications, 19-37.

Ahuvia, A. (2001). Traditional, interpretive and reception-based content analyses: Improving the ability of content analysis to address issues of pragmatic and theoretical concern. Social Indicators Research, 54(2), 139-172.

\section{prosumption \\ on Brazilian fanvideos}

Ludic 
REGE 27,4

\section{8}

Almeida, S.O., Mazzon, J.A., Neto, H.F.H., \& Dholakia, U. (2012). Efeitos da comunidade de origem no participante de comunidades virtuais de marca. RAE - Revista de Administração de Empresas, 52(2), 204-216.

Andrews, D.L., \& Ritzer, G. (2018). Sport and prosumption. Journal of Consumer Culture, 18(2), 356-373.

Baxter, L.A. (1991). Content analysis. In: B.M. Montgomery and S. Duck (Eds.), Studying interpersonal interaction. New York: Guilford Press, 239-254.

Bodet, G., Kenyon, J.A., \& Ferrand, A. (2018). Appetite for or resistance to consumption relationships? A trans-European perspective on the marketisation of football fan relationships. Journal of Consumer Culture 18(2), 317-335.

Boulaire, C., Hervet, G., \& Graf, R. (2010). Creativity chains and playing in the crossfire on the videosharing site YouTube. Journal of Research in Interactive Marketing, 4(2), 111-141.

Buchanan-Oliver, M., \& Seo, Y. (2012), Play as co-created narrative in computer game consumption: The hero's journey in Warcraft III. Journal of Consumer Behaviour, 11(6), 423-431.

Canabaro, A. (2018). Animes de maior sucesso no Brasil. TriCurioso.com. Available from: https://www. tricurioso.com/2018/07/24/animes-de-maior-sucesso-no-brasil/.

Carpenter, J., Moore, M., Doherty, A.M., \& Alexander, N. (2012). Acculturation to the global consumer culture: A generational cohort comparison. Journal of Strategic Marketing, 20(5), 411-423.

Castellano, M., Pinho, J.P., \& Noronha, I. (2018). "Netflix, eu te amo!": o capital emocional no relacionamento entre a empresa de streaming e os consumidores-fãs. Fronteiras-estudos midiáticos, 20(3), 404-417.

Chavanat, N., \& Bodet, G. (2014). Experiential marketing in sport spectatorship services: A customer perspective. European Sport Management Quarterly, 14(4), 323-344.

Chen, K. (2011). Artistic presumption. American Behavioral Scientist, 56(4), 570-595.

Chen, Z.T. (2018). Poetic prosumption of animation, comic, game and novel in a post-socialist China: A case of a popular video-sharing social media Bilibili as heterotopia. Journal of Consumer Culture, Epub ahead of print 12 July, doi: 10.1177/1469540518787574.

Chung, E., Farrelly, F., Beverland, M.B., \& Karpen, I.O. (2018), Loyalty or liability: Resolving the consumer fanaticism paradox. Marketing Theory, 18(1), 3-30.

Collins, S. (2010). Digital fair prosumption and the fair use defense. Journal of Consumer Culture, 10(1), $37-55$.

Costa, F.Z.N., \& Leão, A.L.M.S. (2017). Dispositivo de Potterheads: Organização Pautada na Ordem do Cânone. RAC-Revista de Administração Contemporânea, 21(1), 500-523.

Cova, B., \& Cova, V. (2012). On the road to prosumption: Marketing discourse and the development of consumer competencies. Consumption Markets and Culture, 15(2), 149-168.

Cova, B., Dalli, D., \& Zwick, D. (2011). Critical perspectives on consumers' role as "producers": Broadening the debate on value co-creation in marketing processes. Marketing Theory, 11(3), 231-241.

Cristofari, C., \& Guitton, M.J. (2017). Aca-fans and fan communities: An operative framework. Journal of Consumer Culture, 17(3), 713-731.

Denison, R. (2011). Anime fandom and the liminal spaces between fan creativity and piracy. International Journal of Cultural Studies, 14(5), 449-466.

Drisko, J.W., \& Maschi, T. (2015). Content analysis. New York, NY: Oxford University Press.

Dusi, D. (2016). The perks and downsides of being a digital prosumer: Optimistic and pessimistic approaches to digital presumption. International Journal of Social Science and Humanity, 6(5), 375-381.

Eden, S. (2017). Blurring the boundaries: Prosumption, circularity and online sustainable consumption through freecycle. Journal of Consumer Culture, 17(2), 265-285. 
Edwards, L.. (2019). Copyright: A systemic marketplace icon. Consumption Markets and Culture, 22(1), $74-82$.

Flick, U. (2014). An introduction to qualitative research. 5th ed., Thousand Oaks: Sage Publications.

Fresco, E. (2017). In LeBron James' promotional skin: Self-branded athletes and fans' immaterial labour. Journal of Consumer Culture, 5(2), 1-17.

Freund, K. (2016). "Fair use is legal use": Copyright negotiations and strategies in the fan-vidding community. New Media and Society, 18(7), 1347-1363.

Fuschillo, G. (2020). Fans, fandoms, or fanaticism? Journal of Consumer Culture, 20(3), 347-365.

Giglietto, F., Rossi, L., \& Bennato, D. (2012). The open laboratory: Limits and possibilities of using Facebook, Twitter, and YouTube as a research data source. Journal of Technology in Human Services, 30(3/4), 145-159.

Gonçalves, M.A., Fonseca, M.J., Oliveira, M.O.R., \& Tinoco, M.A.C. (2008). Tendências sobre as comunidades virtuais da perspectiva dos prosumers. RAE - Revista de Administração de Empresas, 7(2), 1-27.

Guschwan, M. (2012). Fandom, brandom and the limits of participatory culture. Journal of Consumer Culture, 12(1), 19-40.

Hartmann, B.J. (2015). Peeking behind the mask of the prosumer: Theorizing the organization of consumptive and productive practice moments. Marketing Theory, 16(1), 3-20.

Hetzel, P. (2002). Plane te conso: Marketing expérientiel et nouveaux univers de consommation. Paris: Editions d'Organisation.

Hewer, P., Gannon, M., \& Cordina, R. (2015). Discordant fandom and global football brands: "let the people sing". Journal of Consumer Culture, 17(3), 600-619.

Hills, M.. (2002). Fan cultures. London: Routledge.

Hills, M.. (2013). Fiske's textual productivity and digital fandom: Web 2.0 democratization vs fan distinction. Journal of Audience and Receptions Studies, 10(1), 130-153.

Hills, M., \& Greco, C. (2015). Fandom as an object and the objects of fandom. MATRIZes, 9(1), 147-163.

Holbrook, M.B. (1999). Consumer value: A framework for analysis and research. London: Routledge.

Holbrook, M.B., \& Hirschman, E.C. (1982). The experiential aspects of consumption: Consumer fantasies, feelings and fun. Journal of Consumer Research, 9(2), 132-140.

Holbrook, M.B., Chestnut, R.W., Oliva, T.A., \& Greenleaf, E.A. (1984). Play as a consumption experience: The roles of emotions, performance and personality in the enjoyment of games. Journal of Consumer Research, 11(1), 728-739.

Holt, D.B. (1995). How consumers consume: A typology of consumption practices. Journal of Consumer Research, 22(1), 1-16.

Jenkins, H.. (1992). Textual poachers: Television fans and participatory culture. New York, NY: Routledge.

Jenkins, H.. (2006). Fans, bloggers and gamers: Exploring participatory culture. New York, NY: New York University Press.

Jenkins, H., Ford, S., \& Green, J. (2013). Spreadable media: Creating value and meaning in a networked culture. New York, NY: New York University Press.

Kizgin, H., Jamal, A., \& Richard, M.O. (2018). Consumption of products from heritage and host cultures: The role of acculturation attitudes and behaviors. Journal of Business Research, 82(1), 320-329.

Kline, S., Dyer-Witheford, N., \& De Peuter, G. (2003). Digital play: The interaction of technology, culture and marketing. Montreal: McGill-Queen's Press.

Kotler, P. (1986). The prosumer movement: A new challenge for marketers, advances in consumer research. Association for Consumer Research, 13, 510-513. 
REGE 27,4

Kozinets, R.V. (1999). E-tribalized marketing? The strategic implications of virtual communities of consumption. European Management Journal, 17(3), 252-264.

Kozinets, R.V. (2001). Utopian enterprise: Articulating the meanings of star Trek's culture of consumption. Journal of Consumer Research, 28(1), 67-88.

Kozinets, R.V., Sherry, J.F., Storm, D., Duhachek, A., Nuttavuthisit, K., \& DeBerry-Spence, B. (2004). Ludic agency and retail spectacle. Journal of Consumer Research, 31(3), 658-672.

Laughey, D. (2010). User authority through mediated interaction: A case of eBay-in-use. Journal of Consumer Culture, 10(1), 105-128.

Leão, A.L.M.S., Mello, S.C.B., \& Vieira, R.S.G. (2009). O papel da teoria no método de pesquisa em administração. Organizações em Contexto, 5(10), 1-16.

Lévy, P. (2007). Inteligência coletiva: Para uma antropologia do ciberespaço. São Paulo: Loyola.

Lincoln, Y.S., Lynham, S.A., \& Guba, E.G. (2018). Paradigmatic controversies, contradictions, and emerging confluences revisited. In N.K. Denzin \& Y.S. Lincoln (Eds.), The Sage handbook of qualitative research. 5th ed., Thousand Oaks, CA: Sage, 108-150.

Liu-Thompkins, Y., \& Rogerson, M. (2012). Ris-ing to stardom: An empirical investigation of the diffusion of user-generated con-tent. Journal of Interactive Marketing, 26(2), 71-82.

Loizos, P.. (2013). Video, film and photographs as research documents. In M. Bauer and G. Gaskell (Eds.), Qualitative researching with text, image and sound. Thousand Oaks: Sage Publications, 97-107.

Mathwick, C., \& Rigdon, E. (2004). Play, flow and the online search experience. Journal of Consumer Research, 31(1), 324-332.

Max, M. (2020). The 25 highest-grossing media Franchises of all time. Titlemax, Available from: https://www.titlemax.com/discovery-center/money-finance/the-25-highest-grossing-mediafranchises-of-all-time/.

Micu, C.C., Chowdhury, T., Micu, A., \& Chaudhuri, A. (2017). What do consumers tweet about? The role of product type and brand belief type on user-generated content. International Journal of Marketing and Business Communication, 6(2), 1-7.

Mikkonen, I., \& Bajde, D. (2013). Happy festivus! parody as playful consumer resistance. Consumption Markets and Culture, 16(4), 311-337.

Milan, A. (2019). What is a Naruto run and how is it linked to Area 51?. Metro.co, Available from: https:/metro.co.uk/2019/07/19/naruto-run-linked-area-51-10427664/.

Miles, M., Huberman, A., \& Saldana, J. (2014). Qualitative data analysis: A methods sourcebook. 3th ed., Thousand Oaks: Sage Publications.

Molesworth, M., \& Denegri-Knott, J. (2007). Digital play and the actualization of the consumer imagination. Games and Culture, 2(2), 114-133.

Montgomery, B.M., \& Duck, S. (1991), Studying interpersonal interaction. New York, NY: Guilford Press.

Morreale, J. (2013). From homemade to store bought: Annoying orange and the professionalization of YouTube. Journal of Consumer Culture, 14(1), 113-128.

Paiva, F.G. Jr, Leão, A.L.M.S., \& Mello, S.C. (2011). Validade e confiabilidade na pesquisa qualitativa em administração. RAC - Revista de Ciências da Administração, 13(31), 190-209.

Pantzar, M. (2000). Consumption as work, play and art: Representation of the consumer in future scenarios. Massachusetts Institute of Technology, 16(3), 3-18.

Parker, R. (2019). Seven ways of looking at fan fiction. WritingThreeSixty, 4(2), 18-27.

Parmentier, M.A., \& Fischer, E. (2015). Things fall apart: The dynamics of brand audience dissipation. Journal of Consumer Research, 41(5), 1228-1251.

Peñaloza, L. (1994). Atravesando fronteras/border crossings: A critical ethnographic exploration of the consumer acculturation of Mexican immigrants. Journal of Consumer Research, 21(1), 32-54. 
Presi, C., Saridakis, C., \& Hartmans, S. (2014). User-generated content behaviour of the dissatisfied service customer. European Journal of Marketing, 48(9/10), 1600-1625.

Rahman, O., Wing-Sun, L., \& Cheung, B.H. (2012). “Cosplay”: Imaginative self and performing identity. Fashion Theory, 16(3), 317-341.

Ritzer, G.. (2014). Prosumption: Evolution, revolution, or eternal return of the same?. Journal of Consumer Culture, 14(1), 3-25.

Ritzer, G., \& Jurgenson, N. (2010). Production, consumption, prosumption: The nature of capitalism in the age of the digital "prosumer". Journal of Consumer Culture, 10(1), 13-36.

Ludic

prosumption

on Brazilian fanvideos

Ritzer, G.. Dean, P., \& Jurgenson, N. (2012). The coming of age of the prosumer. American Behavioral Scientist, 56(4), 379-398.

Sandvoss, C. (2005). Fans: The mirror of consumption. Cambridge: Polity Press.

Seregina, A., \& Schouten, J.W. (2017). Resolving identity ambiguity through transcending fandom. Consumption Markets and Culture, 20(2), 107-130.

Seregina, A., \& Weijo, H. (2017). Play at any cost: How cosplayers produce and sustain their ludic communal consumption experiences. Journal of Consumer Research, 44(1), 139-159.

Siuda, P., \& Troszynski, M. (2017). Natives and tourists of prosumer capitalism: On the varied proprosumer activities of producers exemplified in the Polish pop culture industry. International Journal of Cultural Studies, 20(5), 545-563.

Souza-Leão, A., \& Costa, F. (2018). Agenciados pelo desejo: O consumo produtivo dos potterheads. RAE-Revista De Administração De Empresas, 58(1), 74-86.

Squire, K. (2011). Video games and learning: Teaching and participatory culture in the digital age. New York, NY: Teachers College Press.

Stein, L., \& Busse, K. (2009). Limit play: Fan authorship between source text, intertext and context. Popular Communication, 7(4), 192-207.

Stuart-Menteth, H., Wilson, H., \& Baker, S. (2006). Escaping the channel silo - researching the new consumer. International Journal of Market Research, 48(4), 415-437.

Sugihartati, R. (2020). Youth fans of global popular culture: Between prosumer and free digital laborer. Journal of Consumer Culture, 20(3), 305-323.

Tapscott, D., \& Williams, A. (2006). Wikinomics: How mass collaboration changes everything. New York, NY: Penguin.

Toffler, A. (1980). The third wave. New York, NY: Morrow.

Toffoletti, K., \& Thorpe, H. (2018). The athletic labour of femininity: The branding and consumption of global celebrity sportswomen on Instagram. Journal of Consumer Culture, 18(2), 298-316.

Tombleson, B., \& Wolf, K. (2017). Rethinking the circuit of culture: How participatory culture has transformed cross-cultural communication. Public Relations Review, 43(1), 14-25.

Tourinho, F.S.V., Medeiros, K.S.de, Salvador, P.T.C.DeO., Castro, G.L.T., \& Santos, V.E.P. (2012). Análise de vídeos do YouTube sobre suporte básico de vida e reanimação cardiopulmonar. Revista do Colégio Brasileiro de Cirurgiões, 39(4), 335-339.

Tumbat, G., \& Belk, R.W. (2013). Co-construction and performancescapes. Journal of Consumer Behavior, 12(1), 49-59.

Van Dijck, J. (2009). User like you? Theorizing agency in user-generated content. Media, Culture and Society, 31(1), 41-58.

Van Dijck, J. (2013), The culture of connectivity. a critical history of social media. New York, NY: Oxford University Press.

Waysdorf, A., \& Reijnders, S. (2019). Fan homecoming: Analyzing the role of place in long-term fandom of the Prisoner. Popular Communication, 17(1), 50-65. 
REGE 27,4

Wester, F., \& Jankowski, N.W. (2002). The qualitative tradition in social science inquiry: Contributions to mass communication research. In K.B. Jensen and N.W. Jankowski (Eds.), A handbook of qualitative methodologies for mass communication research. New York, NY: Routledge, 58-88.

Zajc, M. (2015). Social media, prosumption and dispositives: New mechanisms of the construction of subjectivity. Journal of Consumer Culture. 15(1), 28-47.

Ziller, J. (2012). Expressões antropofágicas: apropriação e recriação de vídeos no YouTube. Revista Contemporânea, 10(3), 741-758.

\section{About the authors}

André Luiz Maranhão de Souza-Leão, Facult member at the Administration Graduate Program of the Universidade Federal de Pernambuco. Research fellow of the National Council for Scientific and Technological Development (CNPq). André Luiz Maranhão de Souza-Leão is the corresponding author and can be contacted at: andre.sleao@ufpe.br

Bruno Melo Moura, PhD student at the Administration Graduate Program of the Universidade Federal de Pernambuco.

Walber Kaíc da Silva Nunes, Administration undergraduate student at the Universidade Federal de Pernambuco.

Vitor de Moura Rosa Henrique, Administration undergraduate student at the Universidade Federal de Pernambuco.

Italo Rogerio Correia de Santana, Administration undergraduate student at the Universidade Federal de Pernambuco.

For instructions on how to order reprints of this article, please visit our website:

www.emeraldgrouppublishing.com/licensing/reprints.htm

Or contact us for further details: permissions@emeraldinsight.com 